\title{
THE AFTERMATH OF COVID-19 ON STUDENTS' EDUCATION AND HEALTH IN INDIAN EDUCA- TIONAL INSTITUTIONS: A SURVEY
}

\author{
POOJA MANN \\ Department of Humanities and Social Sciences \\ School of Humanities and Social Sciences, Sharda University \\ Plot No. 32-34, Knowledge Park-III, Greater Noida, Uttar Pradesh-201306, India \\ \& \\ Department of Comparative Literature and Translation Studies \\ School of Letters, Dr. B.R. Ambedkar University \\ AUD Kashmere Gate Campus, Lothian Road, Kashmere Gate, Delhi -110006, India \\ ORCID ID: https://orcid.org/0000-0002-3135-8238 \\ E-mail address: pooja.mann@sharda.ac.in, pmann.17@stu.aud.ac.in \\ BHOOMIKA MANN \\ Department of Economics, School of Liberal Studies \\ Dr. B.R. Ambedkar University \\ AUD Kashmere Gate Campus, Lothian Road, Kashmere Gate, Delhi -110006, India \\ ORCID ID: https://orcid.org/0000-0002-3906-2212 \\ E-mail address: bmann.19@stu.aud.ac.in
}

\begin{abstract}
Aim. This paper aims to bring forth how the basic right of education got adversely affected due to the COVID-19 pandemic. The unplanned and immediate shift to online classes adversely affected the students' physical and mental health as several issues that the students faced were related to the lack of adequate resources.

Methods. The data for this paper were collected through a self-prepared and structured questionnaire, using Google forms, which was then circulated among different stakeholders of the educational institutes. The statistical analysis of the collected data was done using Microsoft Excel.

Results and conclusion. According to the analysis of the survey, smartphones (75\% of the total respondents) are relatively more accessible by students in comparison to computers or laptops (53\%). And even if students had Internet connection (57\%), they faced issues of low data bandwidth (39\%) leading to poor quality of online interaction in classes. Another important result suggested that $57 \%$ of students lacked a quiet room or space to attend the online classes in their homes. Finally, the negative impacts of online classes on the physical and mental health of students were also analysed.
\end{abstract}


Cognitive value. The findings and the analysis of this paper would thus help teachers and institutions to understand students' views and experiences of the pandemic. This understanding would help teachers to plan their teaching accordingly, bridging the digital divide, which would help students learn and grow.

Key words: COVID-19, education, e-learning, inequality, mental health, pandemic, physical health, students

\section{INTRODUCTION}

Coronavirus disease (COVID-19) is a disease caused by a virus called "the novel coronavirus" where the term "novel" stands for "new." The virus was subsequently named severe acute respiratory syndrome coronavirus 2 (SARS-Cov-2) by the International Committee on Taxonomy of Viruses (ICTV) on 11th February 2020. The first human case of COVID-19 was reported in December 2019 in Wuhan City, China, and the first positive case of COVID19 in India was reported on 30th January 2020. By March 2020, the virus had spread across most of the countries of the world and was declared a worldwide pandemic by the World Health Organisation. This was an unprecedented situation, hence no one was prepared to face it.

The number of COVID positive cases in India got very high by June 2021. Out of the 180+ million total cases worldwide, 30+ million cases were found in India (Our World in Data, 2021). Due to the COVID-19 pandemic numerous people died or became more or less seriously ill. Some fortunate people were able to recover with the help of medical treatment. But the cost of the treatment was very high and thus, not all people could afford it. The suffering of people varied on a larger socio-economic scale. Global Human Development declined this year for the first time since the inception of its concept in 1990 (United Nations Development Programme, 2020).

To control the spread of the virus, an immediate lockdown was imposed in several countries which adversely affected the economy of several countries including India. But the pandemic and subsequent lockdown had several severe impacts other than economic recession. Educational institutions were closed in many countries across the globe. This paper focuses on the adverse consequences that COVID-19 had on students' education and health in the educational institutions of India due to schools' closure.

The total number of schools in India, as per the Unified District Information System for Education (UDISE+) (2018-19), is 1,083,678 government schools, 84,614 aided schools, and 325,760 private schools in which 128,497,792 students are enrolled in government schools, 27,525,717 in aided schools, and 83,950,592 are enrolled in the private schools (Kumari, 2020). In addition to schools, there are several colleges and universities in India. Ministry of Human Resource Development (2015) reported that India has 760 universities and 38,498 colleges. Thus, many students are involved in the education sector in India.

The education sector plays a major role in human development and it was impacted gravely as this lockdown resulted in the shutting down of schools, 
colleges, and universities. As per the 28th June 2020 report from the UNESCO, 114 countries stopped schools nationwide. UNESCO also reported how many students were impacted due to the pandemic: 1,570 million learners across the globe, and more than 320 million in India at the school and college level. There was a sudden and unscheduled shift from offline classes to online modes of teaching and learning. Titus Corlatean argues how the COVID-19 has several risks, challenges, and inequities concerning the sudden shift to the e-learning education system (Corlatean, 2020).

The rise of technology in the education sector started much before COVID19. But the usage has increased significantly since COVID-19 (Li \& Lalani, 2020). Several online platforms like Zoom, Google Meet, Google Classroom, and Microsoft Teams were used. This usage exacerbated the existing education inequalities as the lack of adequate resources and skills made the online teaching-learning experience a difficult one. School closures have negative impacts on people at social, educational, and economic levels and affect people across communities, but the impact is especially severe for people belonging to marginalised communities. The basic right to education was thus severely affected by this pandemic.

The recent studies found that online education could only partially replace offline classes and expect a general decrease in the quality of education as a result of the closing of schools. For example, Yong Zhao et al. (2005) analysed the various factors that affect distance education, Edeh Michael Onyema (2019) analysed the various challenges that obstruct integration of emerging technologies in teaching and learning process, and Onyema et al. (2019) analysed the challenges associated with online discussion forum. In 2020, the graph of research on online education got a hike. Various academic researchers did several studies to comprehend the shortcomings of online education in the pandemic. For example, some analysed the learning loss of the students through test scores (Kuhfeld et al., 2020), some analysed how school closures would affect poor children (Van Lancker \& Parolin, 2020), some figured out how the socio-economic skills gap would increase (Haeck \& Lefebvre, 2020), and some investigated the impact of COVID-19 on education (Onyema et al., 2020). Simon Burgess and Hans Henrik Sievertsen (2020) suggested ways to mitigate the negative impacts due to global lockdown of education. With this background, the paper tries to understand the existing literature available on the COVID-19's impact on education across the globe and assess the aftermath of COVID-19 on students' education and health in Indian educational institutions.

\section{METHODOLOGY}

The data for this paper were collected through a self-prepared and structured online questionnaire, using Google forms, which was then circulated among different stakeholders of the educational institutes including faculty, 
students, and parents. The questionnaire was circulated using online platforms like WhatsApp, email, or other online mediums. This method was cost-effective, apt for pandemic situations, and time-efficient as the respondents could answer at their leisure and safe space. The paper attempts to analyse the impact of the closure of educational institutions in India. A total of 200 responses were received from people affiliated with Indian educational institutions. These respondents belonged to different countries. Fig. 1 shows that $79 \%$ of the respondents belonged to India while $21 \%$ belonged to other countries. All the respondents were affiliated with Indian educational institutions (schools, colleges, and universities). They were either affiliated to public or government institutions or private institutions (Fig. 2).

\section{Nation you belong to}

200 responses

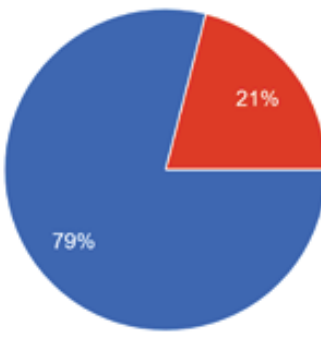

Fig. 1. Nationality of respondents

Source: Own research.

The educational institute you are associated with is a

200 responses

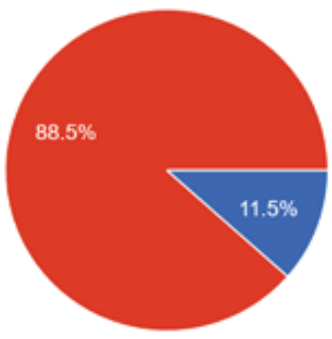

Fig. 2. Respondents' educational institution affiliation Source: Own research. 
The research questionnaire used close-ended questions and one final open-ended question. The questions were uniform for all the respondents which helped in data collection and statistical analysis of the data. The first few questions used multiple-choice questions to gather the general details of the respondents, like name, email address, nationality, educational affiliation, etc. The remaining questions were scaling questions. The scaling questions of the questionnaire were framed in a manner attempting to analyse several concerns that had adverse effects on students' education and health due to COVID-19. For example, the questionnaire focused on how the pandemic and the subsequent lockdown disrupted the learning process; how the economic status and the digital divide made it difficult to access online education for some students; how it affected students' placements; or how it affected their physical as well as mental health, to name a few. The statistical analysis of the collected data was done using Microsoft Excel.

\section{RESULTS}

According to the survey, $53 \%$ of the respondents had access to either a computer or a laptop for attending online classes while $47 \%$ of them were without a computer/laptop (Fig. 3). On the other hand, 75\% of respondents stated that they had access to smartphones. It suggests that smartphones are relatively more accessible by students of various public and private educational institutes in comparison to computers or laptops. Further, 57\% of respondents mentioned that they had Internet connection in their area. However, only 39\% agreed that their data pack or data bandwidth was sufficient to attend all the classes. It suggests that even with increased Internet connection, students faced issues of low data bandwidth leading to poor quality of online interaction in classes.

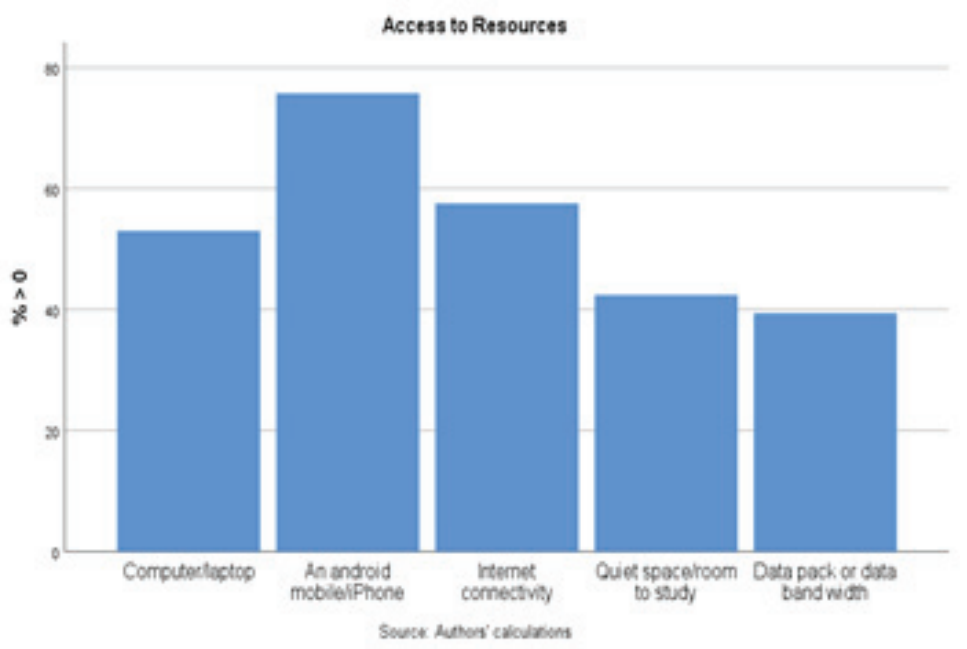

Fig. 3. Respondent's access to resources for online classes Source: Own research. 
Another important but less discussed aspect is the availability of a sound atmosphere at homes. Out of the total respondents, 57\% reported not having a quiet room/place to attend and study in their homes.

The next section was focused on the respondents' teaching-learning experience in online mode. The respondents were asked to choose one option from 1 to 5 (where 1 represents "strongly disagree" and 5 represents "strongly agree") based on the extent they agree with a particular statement. The survey records that $16 \%$ and $28 \%$ of the respondents strongly agreed and agreed (respectively) with "the number of digital devices connected to the Internet in your school/ university to enhance learning and teaching using digital devices was sufficient to conduct online classes smoothly" (Fig. 4). Given that the survey was conducted after almost a complete year from the onset of COVID-19 and the resulting remote learning, it shows that there are still some improvements that are required in the remote-learning process. Moreover, almost half of the respondents mentioned that "acquainting with the e-learning education system was difficult for the teachers" and "acquainting with the e-learning education system was difficult for the students" (Fig. 4). On the other hand, 42\% of the respondents strongly disagreed with the statement "your experience attending online classes was similar to attending offline classes" (Fig. 4). Here, it becomes imperative to understand the reasons for such an experience. The follow-up questions in the survey try to bring out that aspect. Almost half of the respondents either disagreed or strongly disagreed that "asking questions or clarifying doubts in an online class was easy" and "discussing among the students was easy in online classes" (Fig. 4). Apart from that, the respondents also mentioned that paying attention in online classes was difficult for them and the emotional bond among students and teachers was not possible to achieve in the current online learning process (Fig. 4).

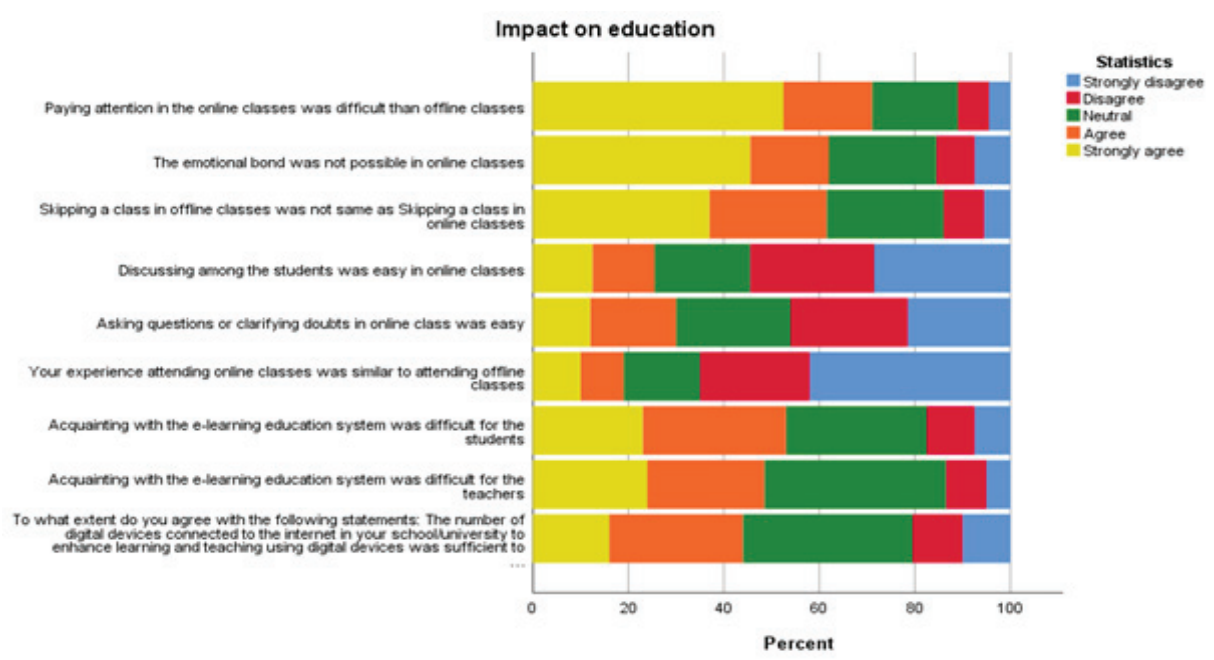

Fig. 4. Respondents' agreement level with the issues faced in online classes Source: Own research. 
The last section of the survey attempted to understand whether respondents feel there are some adverse effects on their physical and mental health or not. The respondents choose one option from a scale of 1 to 5 , where 1 represents "strongly disagree" and 5 represents "strongly agree." First, almost half (48.5\%) of the respondents strongly agreed that focusing on the screen during online classes was not a comfortable experience for them (Fig. 5). Around 20\% of them neither agreed nor disagreed with the statement, i.e., they were neutral. Only $4 \%$ and $11.5 \%$ of the respondents strongly disagreed and disagreed (respectively) with the statement. Second, $52 \%$ of the respondents strongly agreed that "online classes had negative impacts on physical health of students: poor eyesight, no physical exercise, etc." Out of the total, $19.5 \%$ agreed with the statement while $16.5 \%$ were neutral. $6 \%$ of them strongly disagreed and disagreed (each) with the statement. Third, $38 \%$ and $16.5 \%$ of respondents strongly agreed and agreed (respectively) that "online classes impacted mental health of students: causing anxiety, stress, fear, depression." Interestingly, one-fourth (25\%) of the total respondents neither agreed nor disagreed with the statement. While the rest $8 \%$ and $12.5 \%$ strongly disagreed and disagreed (respectively) with the statement.

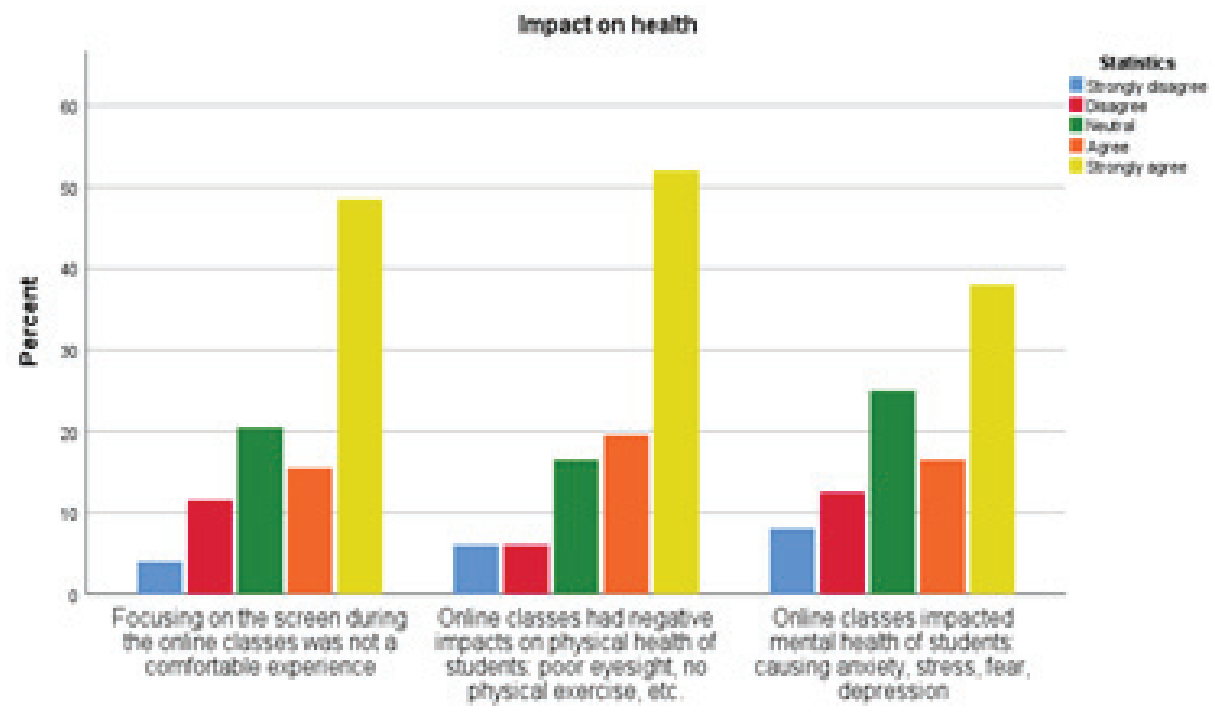

Fig. 5. Respondents' agreement level regarding the impact on health of online classes Source: Own research.

The results show that even though Indian educational institutions shifted to digital learning due to the COVID-19 pandemic, they could not successfully reach everyone due to inaccessibility and unavailability issues related to network, power, digital or electronic devices (like mobiles, laptops, etc.), a suitable learning environment around, and also the skills required for online teaching and learning. All these had an adverse effect not only on the teaching-learning process but also on the physical as well as mental health of students. 


\section{DISCUSSION}

The impact of COVID-19 on education in India was multi-layered. Firstly, the educational process was delayed as it saw cancellation or delay in the scheduled examinations - be it school or college examination, board examination, entrance examination, etc. This delay in the examination led to a delay in the admission process and subsequently, the beginning of the new sessions also got delayed.

Secondly, it impacted adversely the placements of the final year college students. The companies faced economic recession and found it difficult to retain the existing employees. To meet the cost-cutting, they either did not offer any placement to students and some organisations withdrew many placements offers already given to the students. Although the government requested the organisations not to withdraw the already given placement offers as the students would help in overcoming the recession, the organisations did the opposite.

Thirdly, the switch to online classes brought forward the digital divide of India. India was taking several measures to take a digital leap in order to become a digitally advanced country. Although this gap is gradually decreasing, the gap was still significant at the time of the COVID-19 pandemic in 2020 as visible in Fig. 3. This study also reflected the digital divide in India, namely, that $57 \%$ of the respondents had good Internet connection at their homes; out of those $57 \%$, only $39.5 \%$ had access to sufficient data pack or data band; only $53 \%$ of the respondents had their computer or laptop at home (Fig. 3).

It is important to keep in mind that $88.5 \%$ of the respondents were affiliated with private educational institutions (Fig. 2). Private institutions are considered as accommodating the required infrastructure for online classes, but the data shows that not even $60 \%$ of them had adequate resources available to conduct online teaching and learning. However, in remote areas, state-government schools, and vernacular schools the situation was even worse. According to surveys conducted by the National Council of Educational Research and Training (NCERT), the Azim Premji Foundation, Annual Status of Education Report, and Oxfam, between $27 \%$ to $60 \%$ of students were unable to participate in online classes owing to several factors: lack of devices, no or broken Internet connectivity, lack of data packs, etc. (Study IQ education, 2021). The public or governmental institutions also lacked adequate resources and teachers' training to impart education to the children online. The data from the National Sample Survey Office (NSSO) 2017 report showed that merely 6\% of rural households and $25 \%$ of urban households had access to a computer (Study IQ education, 2021).

The National Statistical Office (NSO) survey also shows the digital divide in its 75th report conducted from July 2017 to June 2018. The digital divide is observed across states, cities, villages, and income groups. The report found that only $10 \%$ of households in India have a computer, laptop or tablet and only $25 \%$ have an Internet facility. In cities, $42 \%$ of homes have Internet access. It is only 
$15 \%$ in rural areas. The Internet access in rural areas is one-third compared to urban areas. Only $8.5 \%$ of respondents did not experience any Internet connection issues (Fig. 3). The report showed that the digital presence is best in the capital city of the country, Delhi. But even there it is just 55\%. Odisha has just $10 \% .10$ other states have less than $20 \%$ digital access. It includes big states such as Tamil Nadu and Karnataka. It is shocking to see that residents of the states which are considered to be technical hubs are also facing the scarcity of digital access. The report also pointed out that only $20 \%$ of Indians above the age of 5 have basic digital literacy. It is only $40 \%$ for people belonging to the critical age group of 15-29 years. Hence, more than $50 \%$ of the total population does not have digital literacy. Access to the Internet is very different across the states. Kerala shows the least inequality: urban access $-67 \%$ and rural access - 39\%. But the North-eastern states face almost no Internet access. For example, Assam shows the starkest inequality: $94 \%$ of the impoverished people and $80 \%$ of the rich people have no access to the Internet (NSO, 2019). A large section of the country residents who live in rural areas find it difficult to even arrange the basic amenities like a house, food, water, clothes, or electricity. In such case, how can one think of having access to mobile phones, laptops, or tablets? And even if they had mobile and Internet connection, the high usage of data required for online classes was not affordable. The availability of great Internet speed and high data is mandatory to attend 4-5 hours of online classes per day. Thus, millions of children of marginalised communities saw the scarcity to access online education.

The availability of quiet space or a room to study was another factor which impacted children's education as well as mental health. In a normal routine, most of the family members would go to different places to study or work. But in lockdown, people were forced to stay within the four walls of their houses. The size of a house depends on the socio-economic status of a family. Hence, not every child was able to access a quiet space or room to study. Even students who could afford private education were not able to have a room of their own to study peacefully, and only $42.5 \%$ of respondents agreed to have a quiet place to study (Fig. 3).

Fourthly, considering this digital divide, some volunteers helped marginalised students by teaching in make-shift schools. But these marginalised students had to balance their education along with supporting their families economically in the time of pandemics. The main reason for this was that the parents of these marginalised students were mostly daily wage earners. In the pandemic, these daily wage earners could not earn anything. In this scenario, how would they provide education to their children when there are no financial resources? Would they choose education for their children or would they want them to work and earn for their livelihood? Thus, several students dropped their schools in the middle of the year to look after their families financially. The top two reasons observed were: financial constraints of the family and taking up economic work.

Finally, the fee hikes in such an economic recession were another factor which impacted a large section of the country. The National Sample Survey 
Office (NSSO) 2011 data showed that in a typical family (consisting of parents and two children), children attending school means that $20 \%$ of the household income goes into children's education (NSSO, 2011). With the loss of jobs and paycuts, it became difficult for the parents to pay the hiked fees. Hence, they collectively requested the government to intervene in order to restrict private schools against fee hikes. Especially that the fee hikes have been unreasonable in most cases. For example, Comptroller and Auditor General of India in 2010 audited 25 schools and found that $50 \%$ of the fee charged by private schools is unjustified. Justice Anil Dev Singh Committee checked the accounts of 1100 schools in Delhi, and it turned out that $80 \%$ of them had no need to raise fees based on the $6^{\text {th }}$ pay commission. Although the High Court and Supreme Court have parameters, according to which education is legally an area which is not for profit and commercialisation, the privatisation of schools and colleges have clearly and conveniently overlooked it.

These factors made the experience of attending online classes an uncomfortable one for the students. Fig. 5 shows that $48.5 \%$ of respondents strongly agreed that focusing on the screen during the online classes was not a comfortable experience. This uncomforting situation which happened due to COVID19 had several negative impacts on students' (physical and mental) health. Impact of online classes on the physical health of students due to COVID-19 was observed as there was no physical education, no sports, no exercise, disturbed eating habits, deteriorated sleep cycles, increase of screen time resulting in poor eyesight, long sitting posture in front of a laptop/mobile. But it also affected the mental health of the students as it impacted the social-emotional bond which is very important for primary students. Mahmut Ozer observes how it can lead to detrimental psychological conditions (Ozer, 2020). Due to this negative impact on students, they experienced anxiety, stress, depression, and some even committed suicide. Abdulkarim Al-Rabiaah et al. (2020) and Muhammed Akat and Kasim Karataş (2020) discussed the effects of pandemics on the mental health of students. A total of $52 \%$ of respondents in this study strongly agreed that the online classes had a negative impact on the physical health of students and 38\% strongly agreed that the online classes had a negative impact on the mental health of students (Fig. 5).

Although classroom teaching was shifted to the online one, the latter could not cover other functions of schools such asproviding childcare, taking care of students' health, providing free meals and the ambiance to socialise, etc. For example, Quentin Brummet talked about how the closing of schools would severely affect the differently abled students or those who face problems and need more physical attention and assistance from teachers (Brummet, 2014). Fig. 4 shows that $45.5 \%$ of respondents strongly agreed that the emotional bond was affected in the online classes.

Looking at these issues, education activists suggested declaring 2020 as a "Zero Academic Year" and promoting all the existing students to the next class to motivate their morale. But several steps were adopted by the Indian government to make the sudden and unscheduled shift to the online mode of teaching 
and learning a smooth process. For example, National Council of Educational Research and Training issued guidelines on how to conduct classes when there is no Internet available through telephonic calls; several channels on television, like DDA, were used for education. AICTE allowed a limited opening in educational institutions so that those who do not have the access to the Internet may avail it in the institutions. The government encouraged counselling for the students to address the psychological impacts of the COVID-19 pandemic. For example, counselling helplines like "Kishore manch" were formulated. The government also tried to curb the fee hikes. Also, several digital initiatives were taken by the Ministry of Education and Ministry of Human Resource Development, Government of India. One of them was Diksha, a portal of e-learning content for students; e-Pathshala, an e-learning app for classes 1st to 12th; e-PG Pathshala, which is for postgraduate students; National Repository of Open Educational Resources, a portal which provides a host of resources in multiple languages; SWAYAM, which is a national online education platform hosting 1900 courses; and SWAYAM Prabha, which transmits educational contents on 24/7 basis through 32 DTH TV channels (Jena, 2020).

Despite several difficulties, the shift to online learning opened both students and teachers to a new way of learning. First, it enabled students to access online learning from reputed academicians at global levels using various online meeting platforms like Zoom, Google Meet, Microsoft Teams, etc. This promoted global competency among students. It might not have been possible in the normal setup of the education sector because of the space, time, and economic constraints of people. Second, it promoted their critical learning and thinking process. For example, open-book exams at the University of Delhi in July 2020 used an approach that helped in the critical understanding of the subject among students. This suggests that the focus should not be on schooling, but rather on knowledge and education. Third, the online education also made a significant point regarding the change in the teaching-learning methodology. In the digital era, it is time to try to maximise the inclusion of digital learning even in the offline/face-to-face classes. Thus, change in the course curriculum is also important.

The world is slowly recovering after COVID-19 pandemic. Some schools and universities have partially opened and are expected to open fully in the upcoming months. But one must not forget the socio-economic inequalities that the pandemic brought forward wide open and thus, there are few significant steps that the government should take as a response. First, it should regulate the fee hikes and involve parents in the decision-making process regarding fee hikes. Second, infrastructure for online education needs to be strengthened by providing access to all the students so that no student is deprived of one's basic right to education. Third, teachers and students should be properly trained for digital learning platforms. Fourth, parents should support and understand their children's behaviour and requirements. Fifth, healthy and friendly discussions should be encouraged so that a student can freely share one's feelings and emotions. Finally, new assessment methods should be included 
in the teaching pedagogy (Zhao et al., 2019). Students will require customised and persistent assistance to help them cope up after the pandemic.

In addition to the above-mentioned improvement areas, one can also focus on how online education can be used to aid the digital education that became the need of the hour in the pandemic. Yong Zhao (2020) argues that one should not pretend to equate offline classes with online classes. He explains how one must not compare the two and rather focus on the advantages of online education that can add value to the existing education system (Zhao, 2020).

\section{CONCLUSION}

The unprecedented pandemic of COVID-19 resulted in the closing of educational institutions across the globe. This resulted in an unplanned and instant switch from the offline to online classes, which was the only possible solution to control the pandemic and continue to run the classes. This shift to online classes brought positive changes in the education sector as students were able to access learning not just from their own teachers but also from other reputed academicians across the world which might not have been possible because of the space, time, and economic constraints of the people in the normal setup of the education sector.

However, the shift to e-learning affected students negatively in various ways. It had an impact on their academic, social, and emotional lives. They faced several issues, for example: the delay of examinations, withdrawal of placement offers, lack of adequate resources to attend the online classes, dropping out of schools due to financial constraints, inability to bear the fee hikes, etc. These issues were not faced in the same proportion by everyone. The variation was because of the differences in the social, cultural and economic background of the respondents. Although there were numerous issues, the government of India tried to overcome a number of them. But unfortunately, the attempts could not reach everyone.

The effects of these lacks (be it a smartphone, laptop, computer, Internet, data bandwidth, or one's room) were not limited to the social and economic aspects but also impacted students' physical and mental health. It affected their daily routine which adversely impacted their eyesight and body growth, as well as caused stress and anxiety. These impacts on the physical and mental health of the students are not temporary and may be more visible in the future.

Hence, now when things are getting back to the pre-pandemic state and schools/colleges/universities are opening their doors for the students, one must understand the positive as well as negative impact of this pandemic, subsequent lockdown, and change the online classes made on both academics and students. In this paper, it is also proposed that appropriate measures can be taken by the policymakers to address these issues when students will re-join the face-to-face classes. For example, the government may regulate the fee hikes by involving parents in the decision-making process regarding increasing 
tuition. Another important activity is strengthening infrastructure for online education to provide access to all students so that none of them is deprived of one's basic right to education. The government should also take care of the digital literacy for both teachers and students in order for them to learn how to usedigital learning platforms properly. Parents should also be encouraged to be more supportive and understanding towards their children's behaviour and requirements. What is more, healthy and friendly discussions in which a student can freely share one's feelings and emotions should be encouraged, etc. These conclusions suggest that the public and education authorities, along with other stakeholders, need to carefully collaborate to resolve these issues so that they can promote a healthy and unbiased model of the teaching-learning process in India.

\section{LIMITATIONS}

The sample size for this research is small (i.e., only 200 respondents) as accessing people in the pandemic was a challenging task. Since the nature of the survey conducted was online, this paper assumes that the respondents had an access to a working device (a computer, laptop or smartphone) with some degree of Internet connectivity. The findings of the survey do not fully represent the aftermath of COVID-19 on students' education and health. However, the paper may be a starting point for further research and careful analysis of the current situation.

\section{REFERENCES}

[1] Akat, M. \& Karataş, K. (2020). Psychological effects of COVID-19 pandemic on society and its reflections on education. Turkish Studies, 15(4), 1-13.

[2] Al-Rabiaah. A., Temsah, M. H., Al-Eyadhy, A. A., Hasan, G. M., Al-Zamil, F., Al-Subaie, S., Alsohime, F., Jamal, A., Alhaboob, A., Al-Saadi, B., \& Somily, A. M. (2020). Middle East Respiratory Syndrome-Corona Virus (MERS-CoV) associated stress among medical students at a university teaching hospital in Saudi Arabia. Journal of Infection and Public Health, 13(5), 687-691.

[3] Brummet, Q. (2014). The effect of school closings on student achievement. Journal of Public Economics, 119(November), 108-124.

[4] Burgess, S. \& Sievertsen, H. H. (2020). Schools, skills, and learning: The impact of COVID-19 on education. CEPR Policy Portal. Retrieved June 12, 2021, from https:/ /voxeu.org/article/ impact-covid-19-education.

[5] Corlatean, T. (2020). Risks, discrimination and opportunities for education during the times of COVID-19 pandemic. Working papers 004tc. Research Association for Interdisciplinary Studies.

[6] Haeck, C., \& Lefebvre, P. (2020). Pandemic school closures may increase inequality in test scores. Canadian Public Policy, 46(S1), 82-87.

[7] Jena, P. K. (2020). Impact of pandemic COVID-19 on education in India. International Journal of Current Research, 12(7), 12582-12586.

[8] Kumari, K. (2020). Number of schools in India: State/UT wise total number of Government, Government-aided and private schools. Retrieved July 1, 2021, from https://www.staffnews. in/2020/09/number-of-schools-state-ut-wise-total-number.html. 
[9] Kuhfeld, M., Soland, J., Tarasawa, B., Johnson, A., Ruzek, E., \& Liu, J. (2020). Projecting the potential impact of COVID-19 school closures on academic achievement. Educational Researcher, 49(8), 549-565. https:// doi.org/10.3102/0013189X20965918

[10] Li, C., \& Lalani, F. (2020). The COVID-19 pandemic has changed education forever. This is how. World Economic Forum. Retrieved April 29, 2020, from https://www.weforum.org/ agenda/2020/04/coronavirus-education-global-covid19-onlinedigital-learning/.

[11] Ministry of Human Resource Development. (2015). Annual report on higher education in India - 2015-2016. Retrieved July 5, 2021, from https:/ / www.education.gov.in/sites/upload_files/ mhrd/files/document-reports/AR_2015-16\%20ENGLISH.pdf.

[12] National Sample Survey Office (NSSO). (2011). Level and pattern of consumer expenditure 20092010. NSS 66 ${ }^{\text {th }}$ Round (July 2009-June 2010). Ministry of Statistics and Programme Implementation. National Statistical Organisation: Government of India, December 2011.

[13] National Statistical Office (NSO). (2019). Key indicators of household social consumption on education in India. NSS $75^{\text {th }}$ Round (July 2017-June 2018). Ministry of Statistics and Programme Implementation. National Statistical Office: Government of India, November 2019.

[14] Our World in Data. (2021). Coronavirus pandemic (COVID-19) - the data. Statistics and Research. Retrieved July 1, 2021, from https:/ / ourworldindata.org/coronavirus-data.

[15] Onyema, E. M. (2019). Integration of emerging technologies in teaching and learning process in Nigeria: The challenges. Central Asian Journal of Mathematical Theory and Computer Sciences, 1(August), 35-39.

[16] Onyema, E. M., Deborah, E. C., Alsayed, A. O., Noorulhasan, Q., \& Sanober, S. (2019). Online discussion forum as a tool for interactive learning and communication. International Journal of Recent Technology and Engineering, 8(4), 4852-4859.

[17] Onyema, E. M., Eucheria, N. C., Obafemi, F. A., Sen, S., Atonye, F. G., Sharma, A., \& Alsayed, A. O. (2020). Impact of coronavirus pandemic on education. Journal of Education and Practice, 11(13), 108-121.

[18] Ozer, M. (2020). Educational policy actions by the Ministry of National Education in the times of COVID-19 pandemic in Turkey. Kastamonu Educational Journal, 28(3), 1124-1129.

[19] Study IQ education. (2021, June 4). Covid 19 impact on education and students learning - Current affairs for UPSC, State PSC, SSC, Bank. [Video]. YouTube. Retrieved July 6, 2021, from https:// www.youtube.com/watch?v=WhNkyqNHX4c.

[20] United Nations Development Programme (UNDP). (2020). COVID-19 and human development: Assessing the crisis, envisioning the recovery reports. Human Development Reports. Retrieved July 5, 2021, from http://hdr.undp.org/en/hdp-covid.

[21] Van Lancker, W., \& Parolin, Z. (2020). COVID-19, school closures, and child poverty: A social crisis in the making. The Lancet Public Health, 5(5), 243-244.

[22] Zhao, Y. (2020). Tofu is not cheese: Rethinking education amid the COVID-19 pandemic. ECNU Review of Education, 3(2), 189-203.

[23] Zhao, Y., Lei, J., Yan, B., Lai, C., \& Tan, S. (2005). What makes the difference: A practical analysis of research on the effectiveness of distance education. Teachers College Record, 107(8), 1836-1884.

[24] Zhao, Y., Wehmeyer, M., Basham, J., \& Hansen, D. (2019). Tackling the wicked problem of measuring what matters: Framing the questions. ECNU Review of Education, 2(3), 262-278. 